\title{
Predication on HY County Logistics Park Size Based on GA-BP Neural Network Model
}

\author{
Shijun Yuan \\ Hunan Vocational College of Modern Logistics \\ Changsha, China 410131
}

\author{
Zhongping Zhao \\ Hunan University of Commerce \\ Changsha, China 410205
}

\author{
Jianhua Chen* \\ Hunan Vocational College of Modern Logistics \\ Changsha, China 410131 \\ *Corresponding Author
}

\begin{abstract}
Based on analyzing basic conditions and status quo of modern logistics development at HY County, this article conducts prediction on the demand for logistics through GA-BP neural network model so as to determine the land size of the logistics park, providing references for the construction and development of the logistics park in the county.
\end{abstract}

Keywords-GA-BP; neural network; logistics park; size prediction

\section{INTRODUCTION}

Neural network is in a wide use and it is applicable for many nonparametric and nonlinear classification and problem prediction. When it is adopted for prediction, it needs no assumptions for characteristics of sequences or accurate rules for input and output for systems, and it is a nonlinear mapping relation based on input sets and expectancy mode to train through self learning. This article adopts GA-BP network where BP and GA are combined to predict the logistics park at HY County.

\section{ANALYZING BASIC CONDITIONS NEEDED FOR LOGISTICS DEVELOPMENT OF HY COUNTY}

\section{A. Economic Situation}

In 2016, the regional GDP at HY County totaled 5.95841 billion yuan, increased by $0.5 \%$, judging from industries, the first industry added value totaled 689.997 million yuan, increased by $3.2 \%$; the second industry added value totaled 3131.981 million yuan, decreased by $1.7 \%$; the third industry added value totaled 2136.432 million yuan, increased by $3.0 \%$. The proportion among the three industries was adjusted to $11.5: 52.6: 35.9$ from $11.0: 54.7: 34.3$ of last year, and the industrial structures are optimized continuously. Calculated as per permanent population, the GDP per capita totaled 19,592 yuan, decreased by $2.3 \%$.

The production value of agriculture, forestry, stock raising and fishery at the country totaled 1,208.364 million yuan, increased by $3.2 \%$. The farming lands of crops totaled 34,890 ha, the annual grain yield totaled $90,276.45$ tons, the meat process totaled 13,959 tons, the fishery products yield totaled 2,562 tons, hogs marketable totaled 155,000 heads, sheet marketable totaled 57,600 head, cattle marketable totaled 13,400 heads, poultry marketable totaled 761,000 pieces.

The industrial added value totaled 2925.931 million yuan at the country, occupying $49.1 \%$ of regional GDP. The sellable production value of industrial enterprises with designated size in the county totaled 3.491 billion yuan. Among main products with designated sizes at the county, the yield of sulfuric acid totaled 148,334.19 tons, the yield of electrolytic zinc 88083.17 tons and the yield of electrolytic manganese 77515.3 tons.

The annual retail sales of consumer goods totaled 1,474.509 million yuan, where, retail sales of urban consumer goods totaled $1,100.782$ million yuan, retail sales of rural consumer goods 373.727 million yuan. According to consumption pattern, the wholesale and retail sales totaled $1,286.103$ million yuan, and the retail sales of accommodation and catering industry totaled 188.406 million yuan.

\section{B. Traffics}

There are convenient traffic facilities at HY County, national highways 209 and 319 travel through and meet at the county. It is about $71 \mathrm{~km}$ to Jishou Station of Zhiliu Railway in the south, $150 \mathrm{~km}$ to Zhangjiajie Lianhe Airport in the north and about $100 \mathrm{~km}$ to Guizhou Tongren Daxing Airport in the southwest. With a highway accessing to Zhangjiajie Lianhua Airport built, it only takes about 70-minute drive from Huanyuan to the airport, 39 air lines have been open at Lianhua Airport, flying to Beijing, Shanghai, Guangzhou, Shenzhen and so on; after completion of Changyu Highway, Huanyuan County is only about $400 \mathrm{~km}$ to Changsha and Chongqing, being a mid station connecting southwest and middle west regions.

\section{Resources}

Mineral industry at HY County is leading in economic development in the country, it has been found that the proved mineral resources mainly include manganese, lead and zinc, 
quartz (silica), vanadium, phosphorus, soapstone and stone coal, of which, the Manganese reserves reaches 23 million tons, ranking first in the province and second in the country, called "Oriental Manganese Capital". The lead and zinc reserves reach over 11 million tons, ranking first in the province; the quartz reserves reach 30 million tons, ranking first in the province. The recent-year GDP trends at HY County are given as follows:

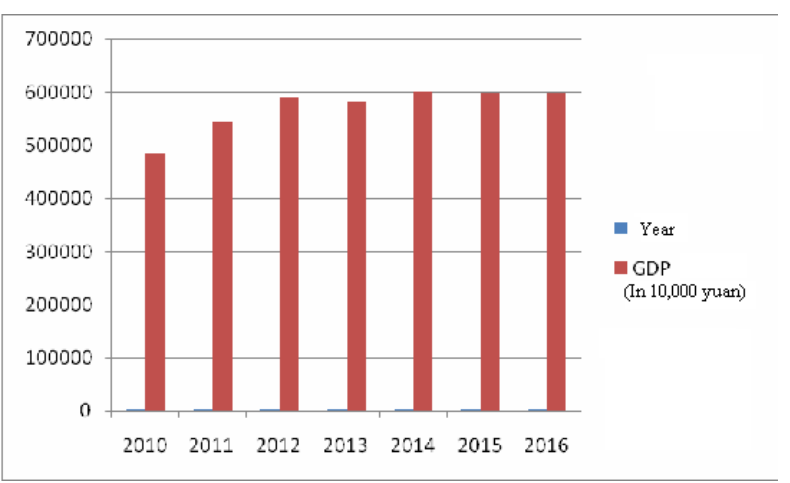

Fig. 1. The recent-year GDP trends at HY County.

\section{STATUS QUO OF LOGISTICS OF HY COUNTY}

\section{A. Logistics Storage}

Most enterprises which engage in logistics storage are mine-related enterprises and main goods source comes from HY County, which is stable. Main characteristics of such logistics storage enterprises include:

- Low requirements on storage, generally the enterprises which engage mineral products provide goods which will be transported to a designated site;

- Generally goods transport fees will be advanced by drivers according to prices for goods transport to the site, it is very slow to recollect the funds, besides, driver have to bear some risks;

- Generally drivers will transport bulk cargos when returning, having no fixed goods sources.

- Prices will be calculated a per ton, about 320 yuan/ton, goods sizes will be also considered.

\section{B. Part-load Traffic}

Retail transports mainly happen at suburbs, generally one or façade rooms need transport business of small hardware, building materials and daily supplies, after reaching the destination, the goods will be fetched by agents. The part-load traffic generally costs little, yet needing a time, for there are no fixed goods sources, needing to transport through vehicle sharing. The transport from HY to Changsha will generally costs about 2,500 yuan per vehicle, and the part-load traffic will depend on the goods size and weight, and the transport from $\mathrm{HY}$ to Changsha will cost about 15 yuan/piece.

\section{Express Delivery}

Main express delivery providers include SF Express, ZTO Express, YTO Express, GTO Express, BEST Express, CY Express, QF Express, TTK Express and so on, all such express providers are agents distributed at urban area in order to make it easy for delivery, however, all of such delivery agents are independent and scattered. Generally the goods after reaching destinations will be delivered to clients directly, needing low requirements on storage, so most express providers just have one or two façade shops or simple places to sort. Surveys show large enterprises such as YTO, STO and BEST generally need $1000-2000 \mathrm{~m} 2$ of storage to sort and $200-500 \mathrm{~m} 2$ of office rooms for business and information process. If a large logistics park is ready, where express providers are willing to settle, it will attract other small-scale express providers and Ecommerce enterprises to settle.

\section{The ScAle PREDiction MOdEl OF HY COUNTY LOGISTICS PARK}

\section{A. Factors Influencing Demands for Logistics}

Logistics demand prediction is a precondition for logistics park size layout, however, currently there is still no an index to accurately describe logistic sizes, and the logistics demand is not clearly defined either, since on the condition that logistics service can meet logistics demand, the cargo volume in a certain period reflects the total logistics demand in the period to some degree, so the cargo volume is taken an index for output information analysis.

The land occupation of logistics parks mainly depends on the cargo volume which yet is related to diverse factors, with other factors kept unchanged, regional GDP, gross industrial output value, postal and telecommunication business are all positively related to the logics volume, the more the logistics volume is, the higher the land occupation for logistics is. In the meantime, total fixed assets investment is an overall indicator reflecting the size and speed of fixed assets; total retail sales of consumer goods is a main indicator reflecting consumer market, all of which can reflect the logistics market to some degree in a certain economic development speed.

\section{B. Logistics Park Land Occupation Prediction Formula}

Logistics park land occupation based on the total logistics volumes:

(Formula 3-1)

Where:

A: Total land occupation of logistics park

C: Total logistics volume, able to be replaced by cargo volume

e: Logistics park efficient, logistics volume on unit area with unit time

P3L Proportion of a third-party logistics in the total logistics market

$\alpha$ : Proportion of a third-party logistics in the logistics market park 


\section{$\mathrm{R}$ : Coefficient of reserved development land}

Since macro policies of Stage and local governments influence the development logistics, and active policies will promote new growth points of logistics, so $\omega$, a correct factor is used in the formula mentioned above; if external environment helps to promote the demand and supply of urban logistics, the $\omega$ value will be a little more than 1 , otherwise, it will be at little less than 1 .

The improved formula is:

(Formula 3-2)

$$
A=\left(\frac{c}{6} \times P_{3 L} \times \alpha\right) \cdot R
$$

\section{THE DEMAND PREDICTION OF HY COUNTY LOGISTICS PARK}

\section{A. Samples and Data Available}

Basic data used, as given in "Table I", are economic indices in 2010-2016, source: HY County Statistics Annual Book and years of HY County GNP and Social Development Statistics Bulletin. According to the data, calculate and get the annual average growth rate of indicators during 2010-2016, with the growth rate kept unchanged, get the predicted value of all indicators in 2020.

Here what we have to know include: HY County abound in mineral resources, main sources of goods transport during 2010-2015 were mineral transport, yet due to the continuous fall of mineral prices, the mineral development at HY County has been reduced greatly, so the statistic data of goods transport were also greatly fluctuating. The logistics park mentioned in this report is mainly providing logistics storage transfer service for basic living materials of urban and rural residents, so the influence of mineral transport shall be removed, and the total retail sales of consumer goods growth trend which has the highest influence on the transport of basic living materials is here used as a reference, and the years of goods transport volume is corrected on the basis of 141 tons in 2016 so as to get the goods transport volume that reflect really basic living needs of urban and rural residents at HY County with mineral transport removed. The corrected data are shown in "Table II":

TABLE I. STATISTICS OF GOODS TRANSPORT AND INFLUENTIAL FACTORS OF HY COUNTY DURING 2010-2016

\begin{tabular}{|c|c|c|c|c|c|c|c|}
\hline No. & Year & $\begin{array}{l}\text { Goods Transport Y } \\
\text { (In } 10000 \text { Yuan) }\end{array}$ & $\begin{array}{c}\text { GDP X1 } \\
\text { (In 10000 Yuan) }\end{array}$ & $\begin{array}{l}\text { Total Industrial } \\
\text { Output Value X2 } \\
\text { (In } 10000 \text { Yuan) }\end{array}$ & $\begin{array}{c}\text { Added Value of } \\
\text { Transport, Storage, } \\
\text { Postal Service } \\
\text { (In 10000 Yuan) }\end{array}$ & $\begin{array}{l}\text { Total Retail Sales of } \\
\text { Consumer Goods X4 } \\
\text { (In } 10000 \text { Yuan) }\end{array}$ & $\begin{array}{l}\text { Total Fixed Assets } \\
\text { Investment X5 } \\
\text { (In } 10000 \text { Yuan) }\end{array}$ \\
\hline 1 & 2010 & 1440 & 482955 & 320796 & 33158 & 76168 & 285020 \\
\hline 2 & 2011 & 1300 & 544942 & 367092 & 35837 & 89134 & 276604 \\
\hline 3 & 2012 & 1266 & 590588 & 391828 & 40620 & 102474 & 248740 \\
\hline 4 & 2013 & 1167 & 582874 & 353773 & 41047 & 107940 & 149417 \\
\hline 5 & 2014 & 800 & 599590 & 358070 & 45118 & 118224 & 160787 \\
\hline 6 & 2015 & 513 & 596664 & 326174 & 45434 & 131972 & 211645 \\
\hline 7 & 2016 & 141 & 595841 & 292593 & 47200 & 147451 & 247069 \\
\hline
\end{tabular}

TABLE II. STATISTICS OF CORRECTED GOODS TRANSPORT VOLUME AND INFLUENTIAL FACTORS OF HY COUNTY DURING $2010-2016$

\begin{tabular}{|c|c|c|c|c|c|c|c|}
\hline No. & Year & $\begin{array}{c}\text { Corrected Goods } \\
\text { Transport Volume Y* } \\
(\text { In } 10000 \text { T) }\end{array}$ & $\begin{array}{l}\text { GDP X1 } \\
\text { (In 10000 } \\
\text { Yuan) }\end{array}$ & $\begin{array}{c}\text { Total Industrial } \\
\text { Output Value X2 } \\
\text { (In 10000 Yuan) }\end{array}$ & $\begin{array}{l}\text { Added Value of Transport, } \\
\text { Storage, Postal Service } \\
\text { (In } 10000 \text { Yuan) }\end{array}$ & $\begin{array}{c}\text { Total Retail Sales of } \\
\text { Consumer Goods } \\
\text { X4 } \\
\text { (In 10000 Yuan) }\end{array}$ & $\begin{array}{c}\text { Total Fixed } \\
\text { Assets } \\
\text { Investment X5 } \\
\text { (In 10000 Yuan) }\end{array}$ \\
\hline 1 & 2010 & 73 & 482955 & 320796 & 33158 & 76168 & 285020 \\
\hline 2 & 2011 & 81 & 544942 & 367092 & 35837 & 89134 & 276604 \\
\hline 3 & 2012 & 91 & 590588 & 391828 & 40620 & 102474 & 248740 \\
\hline 4 & 2013 & 101 & 582874 & 353773 & 41047 & 107940 & 149417 \\
\hline 5 & 2014 & 113 & 599590 & 358070 & 45118 & 118224 & 160787 \\
\hline 6 & 2015 & 126 & 596664 & 326174 & 45434 & 131972 & 211645 \\
\hline 7 & 2016 & 141 & 595841 & 292593 & 47200 & 147451 & 247069 \\
\hline
\end{tabular}

TABLE III. ANNUAL GROWTH RATE AND PREDICTED VALUE OF INDICATORS AT HY COUNTY

\begin{tabular}{|c|c|c|c|c|c|}
\hline & $\begin{array}{c}\text { GDP X1 } \\
\text { (In 10000 } \\
\text { Yuan) }\end{array}$ & $\begin{array}{c}\text { Total Industrial } \\
\text { Output Value X2 } \\
\text { (In } 10000 \text { Yuan) }\end{array}$ & $\begin{array}{c}\text { Added Value of Transport, } \\
\text { Storage, Postal Service } \\
\text { (In 10000 Yuan) }\end{array}$ & $\begin{array}{l}\text { Total Retail Sales of } \\
\text { Consumer Goods X4 } \\
\text { (In } 10000 \text { Yuan) }\end{array}$ & $\begin{array}{l}\text { Total Fixed Assets } \\
\text { Investment X5 } \\
\text { (In } 10000 \text { Yuan) }\end{array}$ \\
\hline Annual growth rate (2010-2016) & 0.04 & -0.01 & 0.06 & 0.12 & 0.01 \\
\hline 2020 & 688807 & 280060 & 59958 & 229553 & 252082 \\
\hline
\end{tabular}

B. GA-BP Neural Network Model Used to Predict Logistics Demand

According to "Table II", take GDP X1, X2, X3, X4, X5 as input information, and the corrected goods transport volume
$\mathrm{Y}^{*}$ during 2010-2016 as output information, which will be used as samples for training, then the data in Table 3 for testing to predict the corrected goods transport volume in 2020. 
To build a GA-BP network, the input layer has 5 nerve cells, the hidden layer has 9 nerve cells, the output layer has 1 nerve cell, the activation functions of input layer and hidden layer are tansig and purelin respectively, the train function shall adopt trainbfg. The iterations shall be 5000, learning speed rate shall be 0.3 , training goal: $1.0 \mathrm{e}-10$, GA's population size shall be 50 , the generation shall be 100 , the crossover probability shall be 0.3 , the mutation probability shall be 0.1 , the procedures will be done through software Matlab, conduct the training through GA-BP neural network, after 120-time trainings, the predicted error reaches the goal scope, getting the goods transport to be 2.14 million tons in 2020 .

\section{Determination of Land Occupation of Logistics Park}

1) Efficient e value of logistics park: During the logistics park layout in the country, generally the e value is designed to 4.1-5.5, according to actual conditions of logistics development at HY County, the logistics park efficient e is set to 4.2 .

2) Proportion of a third party logistics in logistics market $(P 3 L)$ : With regard to the value of proportion of a third party logistics market in the total logistics market, according to researches of $\mathrm{Hu}$ Baoyu, if the layout area has a rapid economic development and the logistics market in a great need, P3L value shall be a little higher than $40 \%$, otherwise, it shall be below $40 \%$. In the meantime, according to the Commercial Trade Logistics data released by Ministry of Commerce News Office, the proportion of a third party logistics in the total logistics market is less than $25 \%$, considering the status quo of a third party logistics providers at HY County, we are determined that the P3L shall be $20 \%$.

3) Proportion value to settle in logistics parkl: Current research results show, influenced by clustering scale benefits, a third-party logistics enterprises will settle in logistics park for development, which is a requirement of market competition and the an inevitable trend for logistics development. The lower the logistics costs are, the higher the logistics service efficiency is, the more apparent the scale economy is, it shall be $30 \%-80 \%$. If the local market is highly developed with large economic aggregate and higher market demand, it shall adopt a higher value among 30\%-80\%, such as Pearl River Delta, Yangtze River Delta and so on, otherwise, it shall adopt a smaller value among 30\%-80\%.

According to the actual development of logistics in HY County, the proportion1 of a third-party logistics business to settle in logistics park shall adopt $50 \%$.

4) $R$ value for reserved development land coefficient: Reserved development land is generally set to expand the logistics park area, which will increase with the increased logistics demand, to determine $\mathrm{R}$ value need to consider many occupations such as economic development, enterprises' logistics cost control, logistics service level and so on. According to the development principle, it is to design long term reserved areas in advance, and its coefficient shall be 1.05 basically.
5) Corrected coefficient $\omega$ Value: HY County is an important bearing platform for the industrial upgrade of Xiangxi industries, and the logistics park will be built into a commercial logistics center spreading to Hunan, Chongqing, Guizhou and Hubei. And authorities will release a string of policies to promote the new growth points of logistics. So $\omega$ is set to be 1.05 .

6) Determination of land occupation by HY county logistics park: Input the goods transport value data and relevant parameters to Formula 3-2, getting that the predicted land occupation by HY County Logistics Park shall be 561.8 ha, equivalent to about $8427 \mathrm{mu}$.

\section{CONCLUSION}

GA-BP neural network mode is used to predict the total regional logistics demand, and the land occupation of the logistics park is used to determine relevant modes that work well to predict the land occupation of the logistics park and can be referenced for the construction and development of the local logistic park.

\section{REFERENCES}

[1] Huang Jianguo, Luo Hang, Wang Houjun, Long Bing, Prediction on Applying GA-BP Neural Network to Analyze Time Sequences [J]. Journal of University of Electronic Science and Technology of China, Sep 2009, pp 687-692.

[2] Chai Yi, Yin Hong-peng, LI Da-jie, et al. Self-adaptation optimize BP neural network design based on the genetic algorithms [J]. Journal of Chongqing University (Natural Science Edition), 2007, 30(4): 91-92.

[3] Byungwhan K, Jungki B. Prediction of plasma processes using neural network and genetic algorithm [J]. Solid-State Electronics, 2005, 49: 1576-1580.

[4] Yang L, Dawson C W, Brown M R, et al. Neural network and $\mathrm{GA}$ approaches for dwelling fire occurrence prediction[J]. Knowledge-Based Systems, 2006, 19 (4): 213-219.

[5] Luo Hang, WANG Hou-jun, LONG Bing. Research about time-serial prediction based on relaxing wavelet neural-net [J]. Computer Engineering and Applications, 2008, 44(8): 16-17. 